Gut, 1980, 21, 793-798

\title{
Role of anaerobic bacteria in the metabolic welfare of the colonic mucosa in man
}

\author{
W E W ROEDIGER* \\ From the Nuffield Department of Surgery and Metabolic Research Laboratory, Nuffield Department of \\ Medicine, Radcliffe Infirmary, Oxford
}

SUMMARY Suspensions of isolated epithelial cells (colonocytes) from the human colon were used to assess utilisation of respiratory fuels which are normally available to the colonic mucosa in vivo. Cells were prepared from operative specimens of the ascending colon (seven) and descending colon (seven). The fuels that were used were the short chain fatty acid n-butyrate, produced only by anaerobic bacteria in the colonic lumen, together with glucose and glutamine, normally present in the circulation. The percentage oxygen consumption attributable to n-butyrate, when this was the only substrate, was $73 \%$ in the ascending colon and $75 \%$ in the descending colon. In the presence of $10 \mathrm{mM}$ glucose these proportions changed to $59 \%$ and $72 \%$. Aerobic glycolysis was observed in both the ascending and descending colon. Glucose oxidation accounted for $85 \%$ of the oxygen consumption in the ascending colon and 30\% in the descending colon. In the presence of $10 \mathrm{mM}$ n-butyrate these proportions decreased to $41 \%$ in the ascending colon and $16 \%$ in the descending colon. Based on the assumption that events in the isolated colonocytes reflect utilization of fuels in vivo, the hypothesis is put forward that fatty acids of anaerobic bacteria are a major source of energy for the colonic mucosa, particularly of the distal colon.

The mucosa of the small and of the large bowel depend upon respiratory fuels to maintain cellular turnover and function. Respiratory fuels can either be derived from the bowel lumen or from the circulation. ${ }^{1}$ The preferred respiratory fuels of the mucosa in the small bowel are glutamine and ketone bodies rather than glucose which is poorly oxidised and largely converted to lactic acid ${ }^{2}$. This lactic acid may be reconverted to glucose in the liver and is a means of conserving glucose during glucose absorption. ${ }^{3}$

The respiratory fuels used by the colonic epithelial cells (colonocytes) have not been studied. In this regard, anaerobic bacteria produce short-chain fatty acids (SCFAs), mainly acetate, propionate, and butyrate, which are water soluble and readily absorbed. ${ }^{4}$ By using a method to prepare isolated surface epithelial cells ${ }^{5}$ it was possible to show that over $80 \%$ of energy needs for the colonic mucosa in the rat were obtained from the absorbed fatty acid,

\footnotetext{
*Address for correspondence: Mr W E W Roediger, Department of Surgery, Prince Henry's Hospital, St Kilda Road, Melbourne, Victoria, 3004, Australia.

Received for publication 14 April 1980
}

n-butyrate. ${ }^{6}$ A comparison between luminal and circulating respiratory fuels used by colonocytes of the rat, established that luminal fatty acids are the preferred fuels and that the order of preference was SCFA $>$ ketone bodies $>$ amino acid $>$ glucose.

Because the human colon normally contains large quantities of SCFAs ${ }^{7}$ it seemed worthwhile to determine whether these fats were used by the human colonic mucosa and whether SCFAs were used differently in the proximal or distal colon. Preliminary observations have already been presented ${ }^{8}$ and this report describes the results in detail. They may be of importance in several clinical conditions affecting the colon.

\section{Methods}

MATERIALS

Colonocytes were obtained from 14 colectomy specimens, seven from the ascending colon-that is, from the ileocaecal valve to the hepatic flexure-and seven from the descending colon - that is, from the splenic flexure to the peritoneal reflection in the rectosigmoid region. The mucosa had no macro- 
scopic or microscopic evidence of disease. All except two cases were obtained from patients with carcinoma of the colon. Mucosa was taken at least $6 \mathrm{~cm}$ from the carcinoma, a distance sufficient to provide mucosa that is cytochemically normal. ${ }^{9}$ One specimen of ascending colon and one of the descending were obtained from patients with Crohn's disease, the area in question being unaffected by the disease.

\section{TECHNIQUES}

Colonocytes were prepared and assessed for metabolic viability as previously described.$^{5}$ The respiratory fuels that were tested, glucose $(10 \mathrm{mM})$, n-butyrate $(10 \mathrm{mM})$, and glutamine $(5 \mathrm{mM})$, as well as a combination of glucose and butyrate with and without $\mathrm{NH}_{4} \mathrm{Cl}(10 \mathrm{mM})$, were selected on the results obtained with rat colonocytes. ${ }^{6}$ Ammonium chloride, which is usually found in the colon, was used because Visek ${ }^{10}$ suggested that it may have an adverse effect on metabolism of mucosal cells. The selected concentration of $\mathrm{NH}_{4} \mathrm{Cl}$ is that which is normally found in the colonic lumen. ${ }^{11}$ Oxygen consumption was measured manometrically ${ }^{12}$ and expressed as $\mu \mathrm{mol}$ per min/g (dry weight) as previously described. ${ }^{5}$

Disappearance of substrates and formation of metabolites-that is, lactate, acetoacetate, $\beta$-hydroxybutyrate, alanine, glutamine, and ammonia-were measured enzymatically, ${ }^{13}$ and expressed as $\mu \mathrm{mol}$ per $\mathrm{min} / \mathrm{g}$ (dry weight). Production of ${ }^{14} \mathrm{CO}_{2}$ from $\left[1-{ }^{14} \mathrm{C}\right]$-butyrate was estimated as follows: $1 \mathrm{ml}$ of cell suspension, equivalent to approximately $5 \mathrm{mg}$ dry weight, was incubated at $37^{\circ} \mathrm{C}$ in $1 \mathrm{ml}$ of physiological saline containing $2 \cdot 5 \% \mathrm{w} / \mathrm{v}$ BSA with radioactively labelled butyrate. Cell suspensions were placed in $25 \mathrm{ml}$ conical flasks sealed with a Suba-seal stopper (Gallenkamp, London, UK) and equipped with a glass centre well. The gas phase was $\mathrm{O}_{2}+\mathrm{CO}_{2}(19: 1 \mathrm{v} / \mathrm{v})$. The initial concentration of $\left[1{ }^{14} \mathrm{C}\right]$-butyrate was $10 \mathrm{mM}$ with a specific activity of $2.1 \times 10^{4} \mathrm{cpm} / \mu \mathrm{mol}$. At the end of incubation $0.5 \mathrm{ml}$ of $10 \mathrm{M} \mathrm{NaOH}$ was injected into the centre well and immediately afterwards $0.5 \mathrm{ml} 10 \% \mathrm{HClO}_{4}$ (v/v) into the cell suspension. The ${ }^{14} \mathrm{CO}_{2}$ was allowed to equilibrate over three hours with $\mathrm{NaOH}$, of which duplicate aliquots of $0 \cdot 1 \mathrm{ml}$ were taken for counting in a liquid scintillation counter (Beckman model 200s). The scintillation fluid, per litre, was a mixture of the following: $600 \mathrm{ml}$ toluene, $400 \mathrm{ml}$ methoxyethanol, $60 \mathrm{~g}$ naphthalene, and $5.5 \mathrm{~g}$ Permablend (Packard Instruments Ltd, Caversham, Berks, UK). Counts per minute in each case were corrected for non-specific activity generated by perchloric acid. Production of ${ }^{14} \mathrm{CO}_{2}$ was expressed as $\mu \mathrm{mol}$ per $\mathrm{min} / \mathrm{g}$ (dry weight).

\section{CALCULATIONS}

From the established pathways of butyrate and glucose metabolism ${ }^{14}$ and the present results, the oxidations of each respiratory fuel could be calculated. Values were calculated from the mean estimations of metabolites appearing or being utilised and expressed as percentages of the measured oxygen consumption. To calculate the $\mathrm{O}_{2}$ requirement to account for butyrate metabolism, the following was taken into consideration: conversion of butyrate to two acetyl-coA requires $1 \mathrm{~mol} \mathrm{O}_{2}$, the oxidation of two acetyl-coA requires 4 mol $\mathrm{O}_{2}$, the conversion of butyrate to acetoacetate requires $1 \mathrm{~mol}$ oxygen and the conversion to $\beta$-hydroxybutyrate $\frac{1}{2} \mathrm{~mol} \mathrm{O}_{2}$. Thus the contribution of butyrate as the fuel of respiration is:

$\left[\left({ }^{14} \mathrm{CO}_{2} \times 5\right)+(\right.$ acetoacetate $\times 1)+(\beta$-hydroxybutyrate $\times \cdot 5)$ ] and is expressed as a percentage value of the oxygen consumption measured manometrically. The rate of glucose oxidation was calculated as follows:

[glucose utilisation-(lactate production $\times \cdot 5)$ ] $\times$ 2.5 and expressed as a percentage value of the oxygen consumption measured manometrically.

\section{Results}

The cumulative oxygen consumption of colonocytes in the ascending colon (Fig. 1) and descending colon

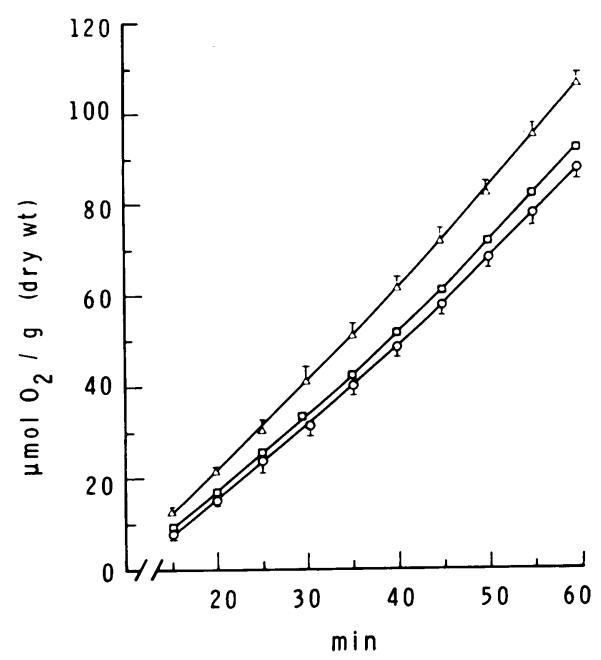

Fig. 1 Cumulative oxygen consumption of human colonocytes of the ascending colon. Mean values of three experiments with $10 \mathrm{mM}$ butyrate $(\triangle-\triangle), 10 \mathrm{mM}$ glucose $(\square-\square)$ or no substrate ( $\square-\square)$. 
Table 1 Effect of substrates on rate of oxygen consumption of human colonocytes

\begin{tabular}{|c|c|c|}
\hline \multirow[t]{2}{*}{ Substrate } & \multicolumn{2}{|c|}{$\begin{array}{l}\text { Rate of oxygen uptake } \\
\text { (umol/min/g dry weight) }\end{array}$} \\
\hline & $\begin{array}{l}\text { Ascending } \\
\text { colon }\end{array}$ & $\begin{array}{l}\text { Descending } \\
\text { colon }\end{array}$ \\
\hline None & $\begin{array}{c}8 \cdot 29 \\
(7)\end{array}$ & $\begin{array}{r}7 \cdot 47 \pm \cdot 69 \\
(7)\end{array}$ \\
\hline Glucose (10 mM) & $\begin{array}{c}9 \cdot 29 \pm \cdot 60 \dagger \\
(7)\end{array}$ & $\begin{array}{c}7 \cdot 88 \\
(7)\end{array}$ \\
\hline Glucose (10 mM + butyrate, $10 \mathrm{mM})$ & $\begin{array}{l}10 \cdot 97 \pm .64 \ddagger \\
(7)\end{array}$ & $\begin{array}{c}9 \cdot 31 \div \cdot 58 \ddagger \\
(7)\end{array}$ \\
\hline Butyrate (10 mM) & $\begin{array}{l}10 \cdot 11 \pm \cdot 56 \dagger \\
(7)\end{array}$ & $\begin{array}{l}9 \cdot 30 \pm \cdot 83 \ddagger \\
(7)\end{array}$ \\
\hline $\begin{array}{l}\text { Glucose }(10 \mathrm{mM}+\text { butyrate } 10 \mathrm{mM} \\
\left.\mathrm{NH}_{4} \mathrm{Cl}, 10 \mathrm{mM}\right)\end{array}$ & $\begin{array}{r}11 \cdot 32 \pm \cdot 83 \\
(6)\end{array}$ & $\begin{array}{r}10 \cdot 55 \\
(5)\end{array}$ \\
\hline Glutamine (5 mM) & $\begin{array}{r}9 \cdot 15 \div \cdot 49 \\
(5)\end{array}$ & $\begin{array}{c}8 \cdot 60 \pm \cdot 49 \\
(5)\end{array}$ \\
\hline
\end{tabular}

Rates of oxygen consumption were measured manometrically and calculated from $20-45$ minute periods of incubation. The data are mean \pm SEM with number of observations in parentheses.

Compared against endogenous oxygen consumption; paired $t$ test.

*NS $\quad \ddagger$ P $<0.005 \quad+P<0.025$

(Fig. 2) was linear indicating that the metabolic performance of cells was good throughout the course of experiments. The addition of glucose, butyrate, and glutamine significantly improved oxygen consumption by isolated cell suspensions (Table 1).

\section{GLUCOSE UTILISATION, GLYCOLYSIS}

The total amount of glucose removed by colonocytes for either oxidation or lactogenesis differed in the ascending and descending colon but was not statistically significant $(\mathrm{P}>0.5$, Student's $t$ test $)$ (Tables 2, 3). In the presence of $10 \mathrm{mM}$ butyrate, glucose utilisation was not altered at either of the sites in the colon. Of the utilised glucose the pro-

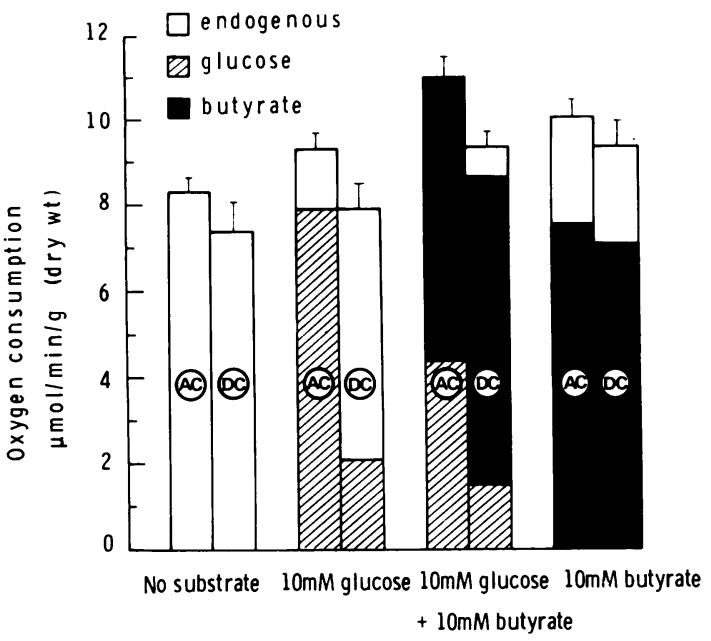

Fig. 2 Contribution of glucose $(10 \mathrm{mM})$, butyrate $(10 \mathrm{mM})$, and endogenous fuels to the total oxygen consumption of isolated colonocytes from the ascending $(A C)$ and descending $(D C)$ colon. Histograms are mean values + SEM of oxygen uptake in $\mathrm{umol} / \mathrm{min} / \mathrm{g} d r y$ weight (see Table l).

portion appearing as lactate was $45 \%$ in the ascending colon and $74 \%$ in the descending colon. The percentage oxygen consumption attributable to glucose oxidation is $85.4 \%$ in the ascending colon and $30 \%$ in the descending colon. Glucose oxidation is suppressed by butyrate from $85.4 \%$ to $40 \cdot 3 \%$ in the ascending colon and from $30 \%$ to $15.8 \%$ in the descending colon (Table 3).

\section{BUTYRATE OXIDATION AND KETOGENESIS}

Oxygen consumption with butyrate, measured by the amount of $\mathrm{CO}_{2}$ generated, was linear over

Table 2 Metabolic changes on addition of substrates to human colonocyte suspension-ascending colon

\begin{tabular}{|c|c|c|c|c|c|c|}
\hline & \multicolumn{6}{|c|}{ Substrate added } \\
\hline & None & Glucose & $\begin{array}{l}\text { Glucose }+ \\
\text { butyrate }\end{array}$ & Butyrate & $\begin{array}{l}\text { Glucose - } \\
\text { butyrate }+\mathrm{NH}_{4} \mathrm{Cl}\end{array}$ & Glutamine \\
\hline Glucose & & $\begin{array}{c}-5 \cdot 74 \pm .97 \\
\text { (7) }\end{array}$ & $\begin{array}{c}-4 \cdot 13 \pm \cdot 51 \\
(7)\end{array}$ & & $\begin{array}{c}-4 \cdot 39 \pm .91 \\
(6)\end{array}$ & \\
\hline Lactate & $\begin{array}{l}\cdot 32 \pm \cdot 04 \\
(7)\end{array}$ & $\begin{array}{l}5 \cdot 14 \pm \cdot 55 \\
\quad(7)\end{array}$ & $\begin{array}{c}4 \cdot 73 \pm \cdot 50 \\
(7)\end{array}$ & & $\begin{array}{c}5 \cdot 26 \pm \cdot 72 \\
(6)\end{array}$ & $\begin{array}{l}\cdot 33 \pm \cdot 06 \\
(5)\end{array}$ \\
\hline Acetoacetate & $\begin{array}{c}\cdot 37 \pm .09 \\
(6)\end{array}$ & $\begin{array}{c}\cdot 15 \pm 03 \\
(7)\end{array}$ & $\begin{array}{l}\cdot 89 \pm \cdot 10 \\
(7)\end{array}$ & $\begin{array}{c}1 \cdot 89 \pm \cdot 15 \\
(7)\end{array}$ & $\begin{array}{l}.99 \pm \cdot 14 \\
(6)\end{array}$ & $\begin{array}{l}20 \pm 05 \\
(5)\end{array}$ \\
\hline Hydroxybutyrate & & & $\begin{array}{l}\cdot 54 \pm \cdot 07 \\
(7)\end{array}$ & $\begin{array}{l}.42 \pm 07 \\
\text { (7) }\end{array}$ & $\begin{array}{l}\cdot 56 \pm .09 \\
(6)\end{array}$ & \\
\hline Ammonia & $\begin{array}{l}2 \cdot 82 \pm \cdot 21 \\
(6)\end{array}$ & $\begin{array}{c}2 \cdot 64 \pm \cdot 25 \\
(6)\end{array}$ & $\begin{array}{c}2 \cdot 29 \pm \cdot 28 \\
(6)\end{array}$ & $\begin{array}{c}2 \cdot 63 \pm \cdot 28 \\
(6)\end{array}$ & $\begin{aligned} & 77=44 \\
& \text { (4) }\end{aligned}$ & $\begin{array}{l}4 \cdot 41+41 \\
\text { (4) }\end{array}$ \\
\hline Glutamate & & & $\begin{array}{l}\cdot 39 \pm \cdot 04 \\
(7)\end{array}$ & $\begin{array}{l}\cdot 44 \pm .05 \\
\text { (7) }\end{array}$ & $\begin{array}{l}\cdot 38 \pm \cdot 03 \\
(6)\end{array}$ & $\begin{array}{l}98 \pm 04 \\
\text { (5) }\end{array}$ \\
\hline Alanine & & & $\begin{array}{l}43 \pm \cdot 02 \\
(7)\end{array}$ & $\begin{array}{c}14 \pm 03 \\
(7)\end{array}$ & $\begin{array}{l}.49+02 \\
(7)\end{array}$ & $\begin{array}{l}.45 \pm .05 \\
(5)\end{array}$ \\
\hline
\end{tabular}

Cells were incubated for 60 minutes. The initial concentration of glucose, butyrate, and $\mathrm{NH}_{4} \mathrm{Cl}$ was $10 \mathrm{mM}$ and of glutamine $5 \mathrm{mM}$. The data are mean \pm SEM of glucose removed $(-)$ or metabolite production expressed as $\mu \mathrm{mol} / \mathrm{min} / \mathrm{g} \mathrm{dry}$ weight. 
Table 3 Metabolic changes on addition of substrates to human colonocyte suspension-descending colon

\begin{tabular}{|c|c|c|c|c|c|c|}
\hline & \multicolumn{4}{|c|}{ Substrate added } & \multirow[b]{2}{*}{$\begin{array}{l}\text { Glucose }+ \\
\text { butyrate }+\mathrm{NH}_{4} \mathrm{Cl}\end{array}$} & \multirow[b]{2}{*}{ Glutamine } \\
\hline & None & Glucose & $\begin{array}{l}\text { Glucose }+ \\
\text { butyrate }\end{array}$ & Butyrate & & \\
\hline Glucose & & $-3 \cdot 61 \pm \cdot 90$ & $\begin{array}{l}-3 \cdot 38 \pm \cdot 79 \\
(7)\end{array}$ & & $\begin{array}{l}-3 \cdot 59 \pm .96 \\
(4)\end{array}$ & \\
\hline Lactate & $\begin{array}{l}\cdot 25 \pm \cdot 05 \\
(7)\end{array}$ & $\begin{array}{c}5 \cdot 36 \pm \cdot 55 \\
\text { (7) }\end{array}$ & $\begin{array}{l}5 \cdot 58 \pm \cdot 56 \\
\text { (7) }\end{array}$ & & $\begin{array}{l}5 \cdot 73 \pm \cdot 60 \\
(6)\end{array}$ & $\begin{array}{l}\cdot 55 \pm \cdot 10 \\
(5)\end{array}$ \\
\hline Acetoacetate & $\begin{array}{l}27 \pm .03 \\
(7)\end{array}$ & $\begin{array}{l}\cdot 14 \pm \cdot 03 \\
(7)\end{array}$ & $\begin{array}{l}\cdot 55 \pm \cdot 06 \\
(6)\end{array}$ & $\begin{array}{c}1 \cdot 39 \pm \cdot 25 \\
(6)\end{array}$ & $\begin{array}{l}\cdot 78 \pm \cdot 15 \\
(6)\end{array}$ & $\begin{array}{l}16 \pm .05 \\
(5)\end{array}$ \\
\hline Hydroxybutyrate & $\begin{array}{l}\cdot 06 \pm .03 \\
(4)\end{array}$ & & $\begin{array}{l}\cdot 44 \pm \cdot 06 \\
(7)\end{array}$ & $\begin{array}{l}\cdot 31 \pm \cdot 05 \\
(7)\end{array}$ & $\begin{array}{l}\cdot 43 \pm .06 \\
(6)\end{array}$ & \\
\hline Ammonia & $\begin{array}{l}2 \cdot 63 \pm \cdot 60 \\
\quad(6)\end{array}$ & $\begin{array}{l}2 \cdot 34 \pm \cdot 82 \\
\quad(6)\end{array}$ & $\begin{array}{l}2 \cdot 07 \pm \cdot 56 \\
(6)\end{array}$ & $\begin{array}{l}1 \cdot 98 \pm \cdot 57 \\
(5)\end{array}$ & $\begin{array}{c}1 \cdot 77 \pm \cdot 31 \\
(6)\end{array}$ & $\begin{array}{l}3 \cdot 49 \pm \cdot 28 \\
(4)\end{array}$ \\
\hline Glutamate & & & $\begin{array}{l}\cdot 30 \pm \cdot 03 \\
(7)\end{array}$ & $\begin{array}{l}\cdot 39 \pm \cdot 04 \\
(7)\end{array}$ & $\begin{array}{l}\cdot 27 \pm \cdot 02 \\
(6)\end{array}$ & $\begin{array}{l}92 \pm \cdot 19 \\
(5)\end{array}$ \\
\hline Alanine & & & $\begin{array}{l}\cdot 50 \pm \cdot 03 \\
(7)\end{array}$ & $\begin{array}{l}\cdot 19 \pm \cdot 04 \\
\quad(7)\end{array}$ & $\begin{array}{l}\cdot 51 \pm \cdot 04 \\
(7)\end{array}$ & $\begin{array}{l}\cdot 43 \pm \cdot 06 \\
(5)\end{array}$ \\
\hline
\end{tabular}

Conditions as given in Table 2.

60 minutes (Fig. 1). Because of lack of cell suspensions evaluation of ${ }^{14} \mathrm{CO}_{2}$ was measured over only 40 minutes (Table 4) but was linear up to 60 minutes in three cases where this could be tested. Production of ${ }^{14} \mathrm{CO}_{2}$ was similar in the ascending and descending colon and addition of glucose or $\mathrm{NH}_{4} \mathrm{Cl}$ did not alter the oxidation of butyrate to $\mathrm{CO}_{2}$.

Human colonocytes produced ketone bodies, mainly acetoacetate, from n-butyrate. Addition of glucose decreased the total ketone body production but increased the appearance of $\beta$-hydroxybutyrate. Ketogenesis diminished in the distal colon, which was significant with regard to acetoacetate but not $\beta$-hydroxybutyrate: for acetoacetate ascending versus descending colon $\mathrm{P}=<0.05$ (Student's $t$ test).

Based on the mean values of ${ }^{14} \mathrm{CO}_{2}$ and metabolite formation, n-butyrate contributed $73 \%$ of the oxygen consumption in the ascending colon and $75 \%$ in the descending colon. In the presence of $10 \mathrm{mM}$ glucose these proportions changed to $59 \%$ and $72 \%$.

\section{GLUTAMINE METABOLISM}

The proportion of glutamine not accounted for as glutamate, ammonia, and alanine can be calculated

Table 4 Production of ${ }^{14} \mathrm{CO}_{2}$ from sodium $n\left[1-{ }^{14} \mathrm{C}\right]$ butyrate

\begin{tabular}{|c|c|c|c|}
\hline & $\begin{array}{l}10 \mathrm{mM}\left[1-{ }^{14} \mathrm{C}\right] \\
\text { butyrate }\end{array}$ & $\begin{array}{l}10 \mathrm{mM}\left[1-{ }^{14} \mathrm{C}\right] \\
\text { butyrate }+ \\
10 \mathrm{mM} \\
\text { D-glucose }\end{array}$ & $\begin{array}{l}10 \mathrm{mM}\left[{ }^{1-14} \mathrm{C}\right] \\
\text { butyrate }+ \\
10 \mathrm{mM} \mathrm{NH}_{4} \mathrm{Cl}\end{array}$ \\
\hline Ascending colon & $\underset{(5)}{1 \cdot 05} \pm \cdot 10$ & $\underset{(4)}{1 \cdot 06} \pm \cdot 05$ & $\underset{(4)}{0.95} \pm .04$ \\
\hline Descending colon & $\underset{(5)}{1.09} \pm \cdot 19$ & $\underset{(5)}{1 \cdot 18} \pm \cdot 22$ & $\frac{1 \cdot 20}{(3)} \pm \cdot 10$ \\
\hline
\end{tabular}

Data are means $\pm \mathrm{SEM}(\mu \mathrm{mol} / \mathrm{min} / \mathrm{g}$ dry weight) of the number of observations in parentheses. from the evolution of ammonia, as there is a one to one stoichiometry between glutamine breakdown and ammonia formation (reaction 1, Fig. 3). Glutamine metabolised beyond glutamate was $0.37 \mu \mathrm{mol}$ per $\mathrm{min} / \mathrm{g}$ (dry weight) in the ascending colon and 0.04 in the descending colon. Of these values the flux across glutamate dehydrogenase to oxoglutarate in the tricarboxylic acid cycle was $18 \%$ in the ascending colon and $0 \%$ in the descending colon.

\section{Discussion}

More than $70 \%$ of the oxygen consumed by colonocytes from the ascending and descending colon was due to butyrate oxidation, a value which is not greatly different from the $80 \%$ observed in colono-

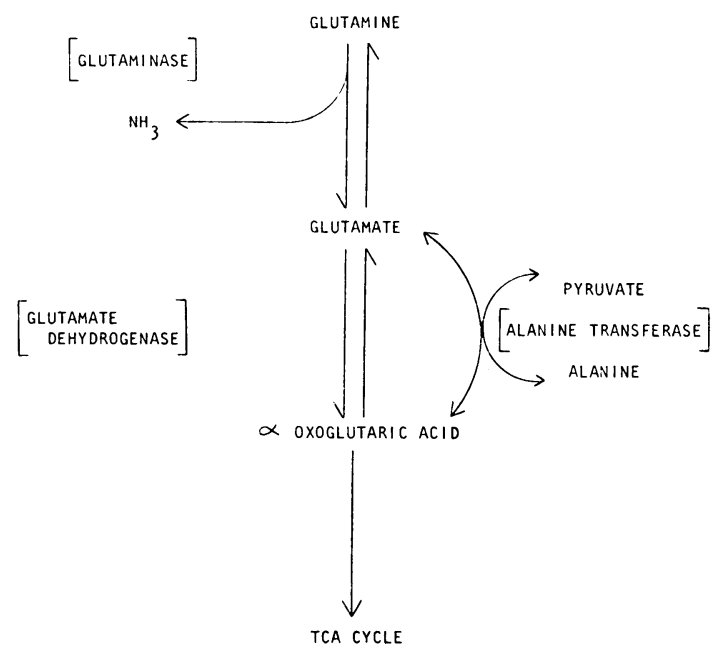

Fig. 3 Reaction 1. 
cytes of the rat. ${ }^{6}$ Part of the butyrate that is oxidised is converted to ketone bodies in a similar way to the mucosa of the rumen and the colon of rabbits. ${ }^{15}$ Ketogenesis thus does not occur only in the mucosa of herbivores but also in the colonic mucosa of omnivores such as man. Ketogenesis generally is an indicator that fats are being oxidised, ${ }^{16}$ and this was confirmed presently by the rate of radioactively labelled $\mathrm{CO}_{2}$ produced from butyrate. For many years ketogenesis in herbivores was taken to indicate energy conservation for the whole organism, especially ruminants which absorb large quantities of SCFAs. ${ }^{17}$ In the light of the present findings it would be preferable to regard SCFAs in man not just as providers of energy to the whole organism but as the predominant energy source for the epithelium of the colonic mucosa.

Colonocytes of the distal colon produce less ketone bodies than those of the proximal colon, an observation also made in the rabbit colon. ${ }^{15}$ In human colonocytes $\mathrm{CO}_{2}$ production from butyrate is the same at both sites. This implies that, for each mole of butyrate that is absorbed and utilised, more enters into the tricarboxylic acid cycle in the distal than proximal colon and suggests that this fatty acid is more important as a respiratory fuel in the distal than proximal colon. Rates of absorption for butyrate are equal per unit area of mucosa in the ascending and descending colon ${ }^{18}$ and changes in ketone body production could therefore not be due to differences in rate of fatty acid absorption. In the presence of glucose butyrate remains a premier fuel of colonocytes and is most pronouncedly oxidised in the distal colon.

Ketogenesis does not occur in the mucosa of small bowel of the rabbit and rat $^{1519}$ and is unlikely to occur in the mucosa of the small bowel of man. Lack of ketogenesis is not unexpected because SCFAs are scarce in the mammalian small bowel, ${ }^{20}$ and there is no measurable butyrate in ileostomy effluent of man (Kennedy, unpublished observation). The ileum is capable of absorbing large quantities of SCFAs ${ }^{21}$ but the epithelial cells of the small bowel (enterocytes) do not increase their oxygen consumption or form ketone bodies when exposed to n-butyrate. ${ }^{15} 19$ The ability to produce ketone bodies and oxidise butyrate is one cardinal metabolic difference between the mucosa of the small and large bowel. Evaluation of ketogenesis and oxidation of butyrate would be worthwhile in disease of the colonic mucosa-as, for example, ulcerative colitis, which is confined entirely to the large bowel.

Another difference between the proximal and distal colon is the extent to which glutamine is metabolised beyond glutamate. As far as glutamine metabolism is concerned, the proximal colon appears to resemble the small bowel, in which (at any rate in the rat) glutamine is extensively oxidised and converted to alanine. ${ }^{19}$ The present finding in the human colon is in line with the suggestion of Pinkus and Windmueller ${ }^{22}$ that there is an aborally decreasing gradient of glutamine utilisation from jejunum to colon. This suggestion was based on finding a decreasing activity of glutaminase (reaction 1) in the mucosa of the small and the large bowel.

All the SCFAs with the exception of acetate are produced by anaerobic bacteria from oligosaccharides, ${ }^{23}$ degradeable fibre, and oligopeptides under conditions of anaerobiosis. The present results indicate that $n$-butyrate is a major respiratory fuel of the colonic mucosa, though it remains to be shown what precise contribution these fatty acids make to the well-being of the colonic mucosa in vivo.

In conclusion, short chain fatty acids in the colon appear to play an important nutrititive role in colonocytes, mediating a symbiotic existence between bacteria and the colonic mucosa of man. These acids warrant further investigation in mucosal diseases of the colon.

My express thanks to Dr Sidney Truelove who made the present research possible and to Sir Hans Krebs, FRS and Dr Patricia Lund for permission to carry out this work in the Metabolic Research Laboratory, Nuffield Department of Medicine, Oxford.

\section{References}

${ }^{1}$ Hanson PJ, Parsons DS. Metabolism and transport of glutamine and glucose in vascularly perfused rat small intestine. Biochem J 1977; 166: 509-19.

${ }^{2}$ Windmueller HG, Spaeth AE. Identification of ketone bodies and glutamine as the major respiratory fuels in vivo for post-absorptive rat small intestine. $J$ Biol Chem 1978; 253: 69-76.

${ }^{3} \mathrm{Krebs}$ HA. The Pasteur effect and the relations between respiration and fermentation. Essays Biochem 1972; 8: 1-34.

${ }^{4}$ McNeill NI, Cummings JH, James WPT. Short chain fatty acid absorption by the human large intestine. Gut 1978; 19: 819-22.

${ }^{5}$ Roediger WEW, Truelove SC. Method of preparing isolated colonic epithelial cells (colonocytes) for metabolic studies. Gut 1979; 20 : 484-8.

${ }^{6}$ Roediger WEW. Functional activity of the colonic mucosa in health and in ulcerative colitis. Thesis Oxford. 1979.

${ }^{7}$ Rubinstein $\mathrm{R}$, Howard $\mathrm{AV}$, Wrong OM. In vivo dialysis of faeces as a method of stool analysis IV: The organic anion component. Clin Sci 1969; 37: 549-64.

${ }^{8}$ Roediger WEW, Truelove SC. Energetics of the colonic epithelial cells (colonocytes) in man: the concept of energy deficiency diseases of the colonic mucosa. Gut 1978; 19: A995. 
${ }^{9}$ Filipe MI, Branfoot AC. Abnormal patterns of mucus secretion in apparently normal mucosa of large intestine with carcinoma. Cancer 1974; 34: 282-90.

${ }^{10}$ Visek WJ. Diet and cell growth modulation by ammonia Am J Clin Nutr 1978; 31: S21-620.

${ }^{11}$ Wrong OM. The role of the human colon in homeostasis. In: Gilliland I, Francis J, eds. The scientific basis of medicine, annual reviews. University of London. Athlone Press, 1971: 192-215.

${ }^{12} \mathrm{Krebs} \mathrm{HA}$, Cornell NW, Lund P, Hems R. Isolated liver cells as experimental material. In: Lundquist $\mathrm{F}$, Tygstrup N, eds. Regulation of hepatic metabolism. (Alfred Benzon. Symposium VI) Copenhagen: Munksgaard 1974: 726-50.

${ }^{13}$ Bergmeyer $\mathrm{HU}$ ed. Methods of enzymatic analysis. 2nd ed, vol 3. New York: Academic Press 1974.

${ }^{14}$ Lehninger AL. Biochemistry: the molecular basis of cell structure and function. New York: Worth, 1975.

${ }^{15}$ Henning SJ, Hird FJR. Ketogenesis from butyrate and acetate by the caecum and the colon of rabbits. Biochem $J$ 1972; 130: 785-90.

${ }^{16}$ Bressler R. Fatty acid oxidation. In: Florkin M, Stotz EH, eds. Comprehensive biochemistry. Amsterdam: Elsevier, 1970; 18: 531-359.
${ }^{17}$ Garton GA. Fatty acid metabolism in ruminants. In: Goodwin TW, ed. Biochemistry of lipids II. Baltimore: University Park Press, 1977; 14: 337-70.

${ }^{18} \mathrm{McNeil}$ NI, Cummings JH. Evidence for regional variation in large intestinal function. Gut 1979; 20: A439.

${ }^{19}$ Watford M, Lund P, Krebs HA. Isolation and metabolic characteristics of rat and chicken enterocytes. Biochem J 1979; 178: 589-96.

${ }^{20}$ Stevens CE. Physiological implications of microbial digestion in the large intestine of mammals: relation to dietary factors. Am J Clin Nutr 1978; 31 : S161-8.

${ }^{21}$ Schmitt MG, Jr, Soergel KH, Wood CM, Steff JJ. Absorption of short-chain fatty acids from the human ileum. Am J Dig Dis 1977; 22: 340-7.

${ }^{22}$ Pinkus LM, Windmueller HG. Phosphate-dependent glutaminase of small intestine: localization and role in intestinal glutaminase metabolism. Arch Biochem Biophys 1977; 182: 506-17.

${ }^{23}$ Vercellotti JR, Salyers AA, Bullard WS, Wilkins D. Breakdown of mucin and plant polysaccharides in the human colon. Can J Biochem 1977; 55: 1190-6. 